\title{
Quality assurance and evaluation system in japanese higher education
}

\author{
Ana Mami Yamaguchi \\ Shuichi Tsukahara
}

Abstract: In this paper we aim to contribute to the debate over accountability and assessment of higher education (HE) by introducing the Japanese system. We first discuss the circumstances and issues surrounding Japanese HE and then examine the historical development of the quality assurance and evaluation system. Since the 1990s, with the implementation of policies that focused on liberalization, deregulation and increased institutional autonomy, the role of the government has shifted from setting strict regulations and quality standards to organizing an evaluation system for assessing the learning outcomes and improving accountability of the HE institutions. Finally, we suggest how Japan may take hints from Brazil in organizing an evaluation system on a national level that can more efficiently support and assess HE institutions.

Key words: Japanese higher education. Quality assurance. Evaluation system. Brazilian evaluation program.

\section{Sistema de Asseguramento da Qualidade e Avaliação na Educação Superior do Japão}

Resumo: Este artigo tem como objetivo contribuir para o debate sobre responsabilização (accountability) e avaliação da educação superior (ES) introduzindo o sistema japonês. Discutiremos primeiro as circunstâncias e o debate sobre o sistema japonês de ES, para depois analisarmos o desenvolvimento histórico do sistema de asseguramento da qualidade e avaliação. Desde 1990, com a implementação de políticas focadas na liberalização, desregulação e aumento da autonomia institucional, o papel do governo federal que até então era de estabelecer regulações estritas e padrões de qualidade para o estabelecimento das instituicões de ES, tem mudado para o papel de organizar um sistema de avaliação que possa medir os resultados de aprendizagem e aumentar a responsabilização das instituições de ES. Finalmente sugerimos o que o Japão pode aprender do Brasil para a organização de um sistema de avaliação em um nível nacional que possa mais eficientemente apoiar e avaliar as instituições de ES.

Palavras-chave: Educação superior do Japão. Asseguramento da qualidade. Sistema de avaliação. Programa de avaliação do Brasil

\section{Introduction}

Japan's world-class educational system combines the universalization of education at all levels — including higher education (HE) — with the assurance of an education of high quality. In contrast, the Brazilian education system has been changing dramatically and rapidly since the 1990s in order to achieve the universalization of basic education and the expansion of higher education of good quality. 
At first glance, these two countries seem to have little in common as they feature very distinct education systems with different priorities and issues; nevertheless, when looking more closely at HE, some similarities become apparent. One point that Japan and Brazil have in common is the reliance on private universities. In Japan, the fast growing economy after the Second World War was accompanied with the expansion of HE. This growth was supported by the private sector that, even nowadays, runs more than $80 \%$ of higher education institutions (HEIs). The quality of education offered at private universities, with the exception of the traditionally prestigious private institutions, varies greatly among institutions. Japan has long controlled the quality of HEIs through the establishment-approval system; the former Ministry of Education, Science and Culture - since 2001 known as the Ministry of Education, Culture, Sports, Science, and Technology (MEXT) — stipulated strict regulations and quality standards for the establishment of HEIs and once an institution was granted permission for establishment, the Ministry expected it to maintain quality. By the 1990s however, the establishment-approval system was deregulated and, at the same time that the HEIs were given more freedom and autonomy to organize their own curriculum, new evaluation systems were introduced to enhance accountability and quality assurance. The HEIs were then required to first perform self-monitoring and self-evaluation, which was later complemented with a third-party evaluation. The OECD Reviews of Tertiary Education: Japan (NEWBY et al., 2009) suggests that with more freedom and autonomy given to the HEIs, it might now be the time for Japan to organize an evaluation system on a national level that can more efficiently support and assess the HEIs.

In this paper we will first provide an overview of the circumstances and issues surrounding Japanese HE, which is essential for understanding the reforms that were put in place to enhance accountability and quality assurance. Second, we discuss the historical development of the quality assurance and evaluation system in Japan from the pre-war period up to the major reforms in the 2000s. Finally, we reflect upon the challenges this evaluation system faces in finding a balance between assuring quality and accountability on the one hand, while at the same time respecting the increased autonomy and academic freedom of the HEIs. In this section, we also show some similarities between the Japanese and the Brazilian evaluation systems. Brazil is a leading country in the world in terms of the organization of a national evaluation system that also includes the direct assessment of the learning outcomes of students. This is an area where Japan can certainly learn from the Brazilian experience. Thus, this paper aims to contribute to the global debate over accountability and quality assessment in HE. 


\section{The circumstances and issues surrounding japanese higher education}

The expansion of HE in Japan is inherently linked to the period of rapid economic growth. The Japanese economy started to grow after the Second World War in the 1950s and it continuously developed until the late 1980s; during this period, to foster a highly qualified workforce became essential to support the growing economy and industrial development. To this end, during the 1960 s the national universities were required to increase programs in the field of natural sciences and engineering and to expand research and graduate courses. On the other hand, to meet the growing demands for HE, the government deregulated the procedure to establish private universities and the rapid quantitative expansion and diversification of $\mathrm{HE}$ was consequently entrusted to the private sector (SAITO, 2011).

From the 1960s, Japanese HE changed from an elite to a mass HE system by expanding in quantitative terms with the increasing participation of the private sector. It also grew increasingly diversified with the introduction of varied professional training programs. Japanese HEIs can be categorized into four different types:

a) Universities and Graduate schools place emphasis on academic research and teaching and operate as "centers of learning." Undergraduate courses award bachelor degrees (4-6 years), whereas graduate courses award master (2 years), doctoral ( 3 years) and professional degrees (2-3 years). Although $88.7 \%$ of the institutions are private (MEXT, 2013), the top 10 universities in Japan are all traditionally 'elite' research universities of which 8 are national (the 7 former imperial universities and Tokyo Institute of Technology) and 2 are private (Keio and Waseda) institutes.

b) Junior colleges are universities that offer short-term courses of 2-3 years and provide practical vocational education; they award subdegree qualifications named associate degree. They play a major role as institutes that train human resources who will work in pre-school education or in the health care industry.

c) Colleges of technology (Kōsen) are planned and coordinated by the National Institute of Technology and provide high-level professional training courses of 5 years for those between the ages of 15 and 19 years; by the completion of the course, the students are awarded with 
a qualification of an associate, with the possibility of changing the diploma to a full-degree type.

d) Professional Training Colleges (different from the above three types of institutions) are relatively free of regulation by MEXT. The purpose of these colleges is to develop professional and practical skills. Thus, they primarily focus on teaching employability skills to their students and provide specialized courses in various areas such as medicine, engineering, business, education, social welfare, carpentry, fashion design, agriculture, graphic design, culinary skills, and hotel management. The length of the courses is in average two years and graduates are awarded technical diplomas.

The enrollment rate in tertiary education in Japan is relatively high with about $70 \%$ of the students who finish high school continuing their studies in some kind of HEI: $47.3 \%$ attend universities, $5.4 \%$ enroll in junior colleges and $17 \%$ continue to professional training colleges (MEXT, 2012a; MEXT, 2014). In terms of absolute numbers, about 3.6 million students were enrolled in HE with 2.8 million in universities, 138 thousand in junior colleges, 58 thousand at colleges of technology and 660 thousand in professional training colleges (MEXT, 2013). In the Japanese HE system it is important to notice that Japan has a very high proportion of private institutions. In 2012, nearly $78 \%$ of the universities and over $90 \%$ of junior colleges and specialized training colleges were private institutions; the only exception are the colleges of technology where $90 \%$ of the institutions are operated by the national government (MEXT, 2012b) (see Table1).

Household expenditure for higher education in Japan is high, not only because three in every four students are enrolled at private institutions but also because, national and public (established by the local government) universities are not tuition free: national universities charge an admission fee of 282,000 yen (about R $\$ 8$ thousand) and an annual fee of 535,800 yen (about R\$ 15 thousand), whereas private universities charge 267,608 yen (about R $\$ 7.5$ thousand) and 859,367 yen (about R $\$ 24$ thousand), respectively (NIAD-UE, 2014).

In the $21^{\text {st }}$ century, Japan has become a mature, slow-growing economy that is characterized by an aging population and a declining birth rate. In 2014, for a total population of 125 million, it reached a record low birth rate of just over a million of new births, while the population of 65 -year-olds (33 million) was double that of the $0-14$ year-olds (16 million). The 18 -year-old population is not 
an exception: it has decreased in the last 10 years from 20 million in 1990 to 12 million in 2012. Even with such a decline of the 18 year-olds, the number of universities continued to rise, which inevitably caused an excess of supply with about $67.5 \%$ of the universities and $47 \%$ of junior colleges unable to fill their enrollment quotas in 2008 (NIAD-UE, 2014).

Finally, in order to comprehend the reforms to enhance accountability and quality assurance in HE, it is essential to understand two additional characteristics of the Japanese HE system.

Table 1 - The expansion of higher education in Japan from 1950 to 2012

\begin{tabular}{ccccc}
\hline Year & $\begin{array}{c}\text { Universities } \\
\text { (private univ.) }\end{array}$ & $\begin{array}{c}\text { Junior Colleges } \\
\text { (private college) }\end{array}$ & $\begin{array}{c}\text { Colleges of } \\
\text { Technology } \\
\text { (private college) }\end{array}$ & $\begin{array}{c}\text { Professional } \\
\text { Training Colleges } \\
\text { (private college) }\end{array}$ \\
\hline 1950 & 201 & 149 & & \\
\hline 1960 & $245(140)$ & 280 & & \\
\hline 1970 & $382(274)$ & 479 & 60 & 2,520 \\
\hline 1980 & $446(319)$ & 517 & 62 & 3,300 \\
\hline 1990 & $507(372)$ & 593 & 62 & 3,551 \\
\hline 2000 & $649(478)$ & 572 & 62 & 3,401 \\
\hline 2008 & $765(589)$ & 417 & 64 & $3,249(3,040)$ \\
\hline 2012 & $783(605)$ & $372(350)$ & $57(3)$ & \\
\hline
\end{tabular}

Source: MEXT “Statistics” (2012). The number of private institutions for Junior College, College of Technology and Professional Training Colleges was available only for the year 2012. The percentage of the private institutions in the other years is expected to be similar to 2012 .

First, in contrast with Japanese primary and secondary schools that are characterized by a rigid system and high scholastic achievement, Japanese universities are often criticized for being "difficult to enter and easy to graduate from"; students undergo a process of intense preparation known as examination hell, sometimes from as early as kindergarten to enter prestigious universities, but then the actual university experience of supposedly 'higher learning' is what some scholars call 'four-year leisure land' (POOLE, 2003). This can be partly explained by the fact that in Japan, about $95 \%$ of the students start seeking jobs at least one year before their graduation and this suggests that companies give more importance on the student's ability at the time of the entrance rather than on the specific knowledge or skills acquired through their studies at the universities. It is thus no exaggeration to state that companies pay more attention 
to the 'status' or 'prestige' of the universities rather than on the actual content the students have mastered during the course (YONEZAWA, 2002).

Second, the expansion of higher education supported by the private sector on the one hand in combination with the dwindling of the 18 year-old population since 1992 on the other makes it difficult for private universities to offer an education of quality for three main reasons: 1) universities need to accept students regardless of their academic skills in order to fill the admission slots; 2) even when the students' academic achievement is not satisfactory, the universities do not oblige the students to withdraw from the courses as long as they pay the tuition fees; 3 ) classes take place in a large lecture-style due to the need to minimize teaching costs (KARIYA, 2012).

The Japanese HE system changed from the pre-war elite education to the post-war mass education and by the 1990s it reached the stage of universalization with more than half of the 18 year-olds enrolled in HE. The reforms and changes in $\mathrm{HE}$ was accompanied with a quality assurance and evaluation system that has also changed to fulfill the different needs and roles of the HE system. We will now discuss in more detail the historical development of the quality assurance and evaluation system in Japanese HE.

\section{Quality Assurance and Evaluation System in Japanese Higher Education}

The historical development of the Japanese quality assurance and evaluation system can be divided into three important periods. The first period ranges from the pre-war to the post-war period with HE characterized by the change from an elitist to a mass HE system; during this period, the quality control of the HEIs relied mostly on the establishment-approval system. The second period starts in the 1990s when the establishment-approval system was deregulated and the self-monitoring and self-evaluation systems were implemented. Finally the third period starts in the 2000s with the introduction of major structural reforms that turned the national universities into autonomous "corporations" and the third-party evaluation system was added to the existing self-monitoring and self-evaluation systems in order to enhance quality and accountability of HEIs.

\subsection{From the Pre-war to the Post-war Period: The Expansion of Higher Education and the Establishment-Approval System for Quality Assurance}

In Japan, the modern HE system began in the late $19^{\text {th }}$ century with the foundation of the Tokyo Imperial University (nowadays known as University 
of Tokyo) in 1877. In the subsequent years, an additional 6 imperial universities were established in the major cities (Kyoto in 1897, Tohoku in 1907, Kyushu in 1910, Hokkaido in 1918, Osaka in 1931, and Nagoya in 1939), and several polytechnics in Tokyo with prestigious reputations became universities and colleges, such as the Tokyo Institute of Technology (1929) and Hitotsubashi University (1920). At the same time, prestigious private institutions such as Keio-Gijuku, which had originally been established as a Dutch-language School, became Keio University (1890) and Tokyo Senmon Gakko or Tokyo College became Waseda University (1902). In 1903, the government enacted the Specialized School Order to categorize the various types of institutions as 'specialized schools' and in 1918, with the promulgation of the University Order, many of the single-faculty institutions became universities (OBA, 2005). The expansion of HE during the pre-war period was hence controlled by the central government through the establishment of strict regulations and quality standards to grant permission for the establishment of HE institutions (YONEZAWA, 2002).

Japanese universities were, during this period, stratified according to their status, history and reputation. The seven imperial universities (national universities) along with a small number of other prestigious national universities and a few private universities like Keio and Waseda constituted the 'elite institutions' (KITAGAWA; OBA, 2010). Private institutions were financially independent from the government and relied on revenues from students while the imperial universities were treated as 'elite research institutes' and were heavily subsidized by the government (OBA, 2005; YONEZAWA, 2007).

Japan went through a major educational reform after the Second World War under the American Occupation (1945 to 1952). In 1947 the School Education Law was enacted and proposed the so called "6-3-3-4" new school system with 6 years of elementary school, 3 years of lower secondary school, 3 years of upper secondary school and 4 years of university. Compulsory education was extended to 9 years and the various institutions of HE were integrated into 4-year universities. During this period, the imperial universities lost their formal status as 'elite institutions' and were integrated into the newly created university system in which all the national universities would have the same legal status (OBA, 2008; SAITO, 2011; MEXT, 2015).

The quality assurance of HEIs relied on two main bodies: 1) the Standards for the Establishment of Universities (SEU): it was enacted by the Japanese government in 1956 and stipulated standards and regulations to the establishment of HEIs such as the organization of the curriculum, the courses that should 
be offered, the student-staff ratio, and the required space per student; 2) the Japan University Accreditation Association (JUAA): set up in 1947, it was a non-governmental organization for accreditation of HEIs and had the purpose to control the quality of the post-war newly established HEIs (OBA, 2004). The JUAA was composed of 46 members from national, local public and private HEIs and established its own university standards with the promulgation of University Standards (1947) and the Post Graduate Standards (1949). In 1952 the JUAA provided accreditation to the first 38 universities (18 national, 2 local public and 18 private) under the new rules (JUAA, 2015).

The quality of HEIs during the post-war rapid expansion was assured by the government strict standards and regulations stipulated by the SEU, combined with the JUAA voluntary institutional accreditation system. Most of the HEIs, however, only applied for charter approval to the government and did not seek to be accredited by JUAA. Since accreditation by JUAA was voluntary and no legal sanctions existed for failing to apply for it, quality assessment of HEIs tended to be limited to the SEU with emphasis put on 'numerical' requirements such as student-staff ratio, number of students per faculty, building area and facilities rather than on educational and research activities (OBA, 2004; YONEZAWA, 2002). In the 1980s, the Ministry started to consider the introduction of an evaluation system that would assess the quality of HEIs after their initial establishment.

\subsection{0s: the Universalization of $\mathrm{HE}$ and the Self-monitoring and Self-Evaluation Systems}

The first major reform in post-war Japanese education was the revision of the SEU in 1991, which moved quality assessment more towards decentralization and self-evaluation. It abolished the minimum requirements on general education, loosened the regulations on the curriculum and provided the HEIs with freedom and flexibility to implement their own educational programs. Moreover, the revision also included new regulations in which the HEIs had to monitor their educational and research activities through a self-monitoring and self-evaluation system. By 1997, 83.7\% of the universities had carried out the self-evaluation and self-monitoring at least once, and $56.4 \%$ had done so more than once. With regard to the introduction of an external or third-party evaluation system, the University Council -established in 1987 by the Ministry of Education, it is composed by university rectors, business executives and researchers to deliberate on HE policies- opposed it with the argument that it 
would affect the academic freedom and autonomy of the institutions (YONEZAWA, 1999; SAITO, 2011).

A survey conducted in 1998 by Hiroshima University's Research Institute for Higher Education (RIHE) found that, although the self-monitoring and self-evaluation system was implemented differently among universities, this system had an impact on promoting reforms and improving the quality of HEIs. Moreover, the findings show that the national universities had the tendency to focus their evaluation on research activities because research performance is directly connected to the acquisition of additional revenue other than the basic revenue provided by the government. The private universities on the other hand, tended to focus their evaluation on students' enrollment and graduate student performance because competitiveness in student recruitment is their main source of revenue (YONEZAWA, 2002).

In 1999 the self-monitoring and self-evaluation system that had thus far been optional became compulsory and all universities were now required to conduct these evaluations of which the results were to be made public. As a result, almost $100 \%$ of the universities perform these self-reviews, which now have become part of their routine activities (KUSHIMOTO, 2010).

The self-evaluation and self-monitoring activities played an important role in promoting reforms and improving quality but in order to promote further institutional reforms and to build globally competitive HEIs, the Ministry of Education felt it was necessary to reconsider the once criticized third-party evaluation system.

\subsection{0s: Globalization of HE and the Plural Evaluation System}

In 1998, the University Council issued a report "Vision for the Universities in the $21^{\text {st }}$ Century and Reform Measures" which included the following major proposals for HE: 1) to enhance the quality of teaching and research by nurturing the problem search and solving abilities of students; 2) to ensure the autonomy of the HEIs by providing a more flexible educational and research environment; 3) to decentralize the administrative structure with increased autonomy in the decision making process and implementation of projects; 4) to establish a pluralistic evaluation system: self-monitoring and self-evaluation system combined with a third-party evaluation system (UNIVERSITY COUNCIL, 1998).

One major structural reform that took place in 2004 was the incorporation of all 86 national universities, which became national university corporations (NUCs). With this change, national universities gained an independent adminis- 
trative system with autonomy in both governance and funding. The relationship between the government and the NUCs is one where MEXT provides administrative guidance and feedback regarding six-year mid-term goals and plans proposed by the NUCs; while these mid-term plans are used by the NUCs to request for governmental funding, the government uses it as a base to evaluate the level of achievement. MEXT uses the result of this evaluation to decide on the financial rewards or punishment (in the worst case, discontinuation of funding) for the individual NUCs. It is also used as a basis for formulating the next mid-term proposal. Hence, the NUCs were now forced to formulate a clear proposal of mid-term goals and plans based on which their performance would be evaluated, while the government had to structure an evaluation system to improve accountability (OBA, 2004). To this end, MEXT established the National University Corporation Evaluation Committee (NUC-EC) to assess NUCs performance against their annual plans, mid-term plans and mid-term objectives for education, research and management. The National Institution for Academic Degrees and University Evaluation (NIAD-UE) has been delegated to evaluate the achievement of mid-term objectives in terms of education and research (NIAD-UE, 2015a). The evaluation is carried out at the end of each academic year, in the middle of the term and finally a performance-based evaluation conducted at the end of a 6 year-term.

Moreover, the School Education Law was amended to deregulate the Standards for the Establishment of the Universities (SEU) and simplify the standards for the establishment of universities, and to increase the autonomy and flexibility of the HEIs in reorganizing faculties and the curriculum. Along with these changes, MEXT established the Certified Evaluation and Accreditation (CEA) system to strengthen evaluation and improve accountability of the HEIs. All HEIs are obligated to undergo a comprehensive evaluation of their education, research, organizational operations, and facilities by third-party evaluation agencies in charge of accreditation and assessment, which are certified by MEXT. As of April 2014, there are four CEA agencies:

a) NIAD-UE (National Institution for Academic Degrees and University Evaluation) created in 2004, is the only organization certified to undertake evaluations of all types of HEIs as well as professional graduate schools (NIAD-UE, 2015b).

a) JUAA(Japan University Accreditation Association) established in 1947 and certified in 2004 to undertake the evaluations of universities, junior colleges, law schools, and professional graduate schools of business, 
public policy, public health and intellectual property studies (JUAA, 2015).

b) JIHEE (Japan Institution for Higher Education Evaluation) founded by the Association of Private Universities of Japan in 2000 as a Research Institute for Independent Higher Education (RIIHE). In 2004 RIIHE was authorized by MEXT to become JIHEE and certified as an institution to undertake evaluations of universities, junior colleges and fashion business professional graduate schools (JIHEE, 2015).

c) JACA (Japan Association for College Accreditation) established in 1994 as an organization to support and promote the improvement of quality of junior colleges, was certified in 2005 as an organization to undertake evaluation of all junior colleges (JACA, 2015).

In addition, there are another $8 \mathrm{CEA}$ agencies that conduct evaluation of professional graduate schools, such as the Japan Law Foundation, the Institute for the Evaluation of Teacher Education, and Japan Accreditation Board for Engineering Education. All these CEA agencies develop and use their own evaluation criteria and standards, and they disclose their evaluation results to the public. The underlying rationale for the coexistence of various CEA agencies is that a diverse HE system needs differentiated standards to evaluate the different types of HEIs.

The present quality assurance and accountability system in Japan is thus comprised of 1) an establishment-approval system; 2) a self-monitoring and self-evaluation system; 3) a CEA system and 4) a National University Corporation Evaluation system. This rather complex and seemingly comprehensive evaluation system is criticized on a number of grounds: first, it has not been sufficiently developed and is not efficient; second, the evaluation practices are time consuming to the academic and administrative staff members engaged in the evaluation activities, at times even having a negative impact on education and research activities. This situation is particularly worrisome in national university corporations because they need to prepare for the annual evaluation, in addition to the mid-term and the end of a 6 year-term evaluation (WATANABE, 2008; OBA 2005).

The Japanese evaluation and accreditation system was made more rigid to increase accountability and to enhance reforms in order to construct internationally competitive HEIs. It is still uncertain, however, whether this system will foster strong and competitive institutions. 


\section{Final Considerations}

The Japanese higher education system has changed from the pre-war elite education to a post-war mass education and it is now moving towards a universal and global HE system. In recent years, due to increased globalization of the HE market and competition with universities around the world, Japan is under pressure to create "World-Class Universities" that can be internationally competitive with high-quality educational outcomes and that can attract international students. Moreover, in the "Education Rebuilding Council 2013" the government announced a new target to have 10 Japanese universities among the top 100 in the world. Nevertheless, the plan to build world-class universities means that governmental funding will increasingly concentrate on the traditional top universities, i.e., the former imperial universities and the traditionally prestigious private universities. Amano (2014) criticizes that these policies are producing a few "strong" universities and many "weak" ones, resulting in greater inequalities in competitiveness among universities and widening the gap between the top universities and the middle/lower-range universities.

Since the early 1990s, the HE policies that focused on liberalization, deregulation and increased institutional autonomy created two paradoxes for Japanese HE: 1) the liberalization paradox: the phenomenon that free competition rather than creating more equal opportunities to all universities to compete at the same level, is leading to the creation of an even more hierarchical HE system with the 'traditional' HEIs maintaining their elite status as 'top research universities'; 2) the deregulation paradox: the phenomenon that deregulation with flexible standards and increased institutional autonomy led to the introduction of an even more rigid evaluation system.

Japan has in the last 20 years developed a rather complex and comprehensive evaluation system that developed from the establishment-approval system to a system that also includes the self-monitoring/evaluation and the third-party evaluation carried out by different CEAs. We find similarities between Japan and Brazil in regard to institutional and educational environment assessment. As is the case in Brazil, in Japan the institutional evaluation also relies on a self-evaluation and self-monitoring system and, in regard to the educational environment evaluation, both countries carry out periodic on-site visits to assess academic staff, student-staff ratio, number of students per faculty and infrastructure, among others.

The evaluation activity where Brazil excels is in regard to the implementation of an exam on a national level to assess the students' learning outcomes, 
the National Exam for the Assessment of Student Performance (ENADE). While the Japanese system relies mostly on indirect assessment with the use of students' surveys as a method to assess learning outcomes (YAMADA, 2014), the Brazilian evaluation system conducts direct assessment with the use of ENADE as one of the major criteria to assess learning outcomes of the undergraduate programs and institutions.

In Japan, the introduction of a standardized national exam like ENADE to assess the learning outcomes may be perceived to be 1) a factor that could limit the academic freedom and autonomy of the HEIs in organizing and improving the curriculum and educational programs; 2) not appropriate to evaluate the diverse HEIs because there is a need to utilize different standards and exams for the different types of institutions; 3 ) not enough to improve the curriculum and consequently the quality of education because it does not reflect the learning process of the students. Moreover, in Japan there are no regulations that stipulate the minimum standard curriculum. Nevertheless, the need to evaluate each type of HE institution by different CEAs as well as the vision to holistically assess the student's outcome through indirect assessment, has created a system of quality assurance that is not very efficient and time consuming for the academic and administrative staff members. To make the Japanese evaluation system more efficient, the OECD Reviews of Tertiary Education: Japan [Newby et al. 2009] suggests the establishment of a national center for higher education with the purpose of gathering the information from the different CEAs and supporting the HEIs with information exchange to improve their educational activities. Moreover, it also suggests that Japan should consider the possibility in participating in assessment of students' outcomes developed by international organizations.

Japan has reached the stage of universalization of HE and is now more than any other period in history under pressure to increase accountability and organize an efficient evaluation system that can assess more precisely the learning outcomes and assure a level of quality that is globally competitive. Gonyea (2005) suggests that the use of both indirect and direct assessment can complement one another and offer a more holistic view of the learning outcomes. From this perspective, Brazil - though still on the stage of massification of HE - has already built an evaluation system on a national level with the establishment of the National Higher Education Evaluation System (SINAES) in 2004. SINAES was established with the purpose to evaluate the HEIs in a holistic way by combining the national HE database with the results of self-evaluation, third-party evaluation and ENADE. To Japan, a further investigation of the 
Brazilian national evaluation system can certainly provide important clues on how to develop a national system to support and access the HEIs.

Japanese HE is under pressure to continually change in order to cope with the demands of a global economy that requires globally competitive HEIs; with the role of the government shifting from setting regulations and standards to the organization of an evaluation system that can more efficiently assess quality and increased accountability of the HEIs, now may be the time to Japan to organize an evaluation system on a national level that can not only assess quality and increase accountability but can also provide assistance to the HEIs to improve learning outcomes and educational activities while respecting HEIs autonomy and academic freedom.

\section{References}

AMANO, Ikuo. Globalization and higher education reforms in Japan: the obstacles to Greater International Competitiveness. 2014. Available in: $<$ http://www.nippon.com/en/in-depth/a02801/>. Accessed: 1 jun. 2015.

GONYEA, R. M. Self-reported data in institutional research: review and recommendations. New Directions for Institutional Research, Survey Research Emerging Issues, San Francisco, v. 127, p. 73-89, 2005.

JACA. About. 2015. Available in: <http://www.jaca.or.jp/english/ english1_1.html>. Accessed: 11 ago. 2015.

JIHEE. About JIHEE. 2015. Available in: <http://www.jihee.or.jp/en/about/ objectives.html>. Accessed: 23 may 2015.

JUAA. About JUAA. Japan University Accreditation Association. 2015. Available in: $<$ http://juaa.or.jp/en/about/index.html $>$. Accessed: 11 ago. 2015.

KARIYA, Takehiko. Higher education and the Japanese Disease. 2012. Available in: <http://www.nippon.com/en/in-depth/a00602/>. Accessed: 23 may 2015.

KITAGAWA, Fumi; OBA, Jun. Managing differentiation of higher education system in Japan: connecting excellence and diversity. Higher Education, Springer Netherlands, v. 59, p. 507-524, 2010. 
KUSHIMOTO, Takeshi. Outcomes assessment and its role in self-reviews of undergraduate education: in the context of japanese higher education reform since the 1990s. Higher

. Higher Education in Japan. Tokyo: MEXT, 2012a.

Available in: <http://www.mext.go.jp/english/highered/_icsFiles/ afieldfile/2012/06/19/1302653_1.pdf>. Accessed: 23 may 2015.

. Statistical abstract 2012 edition 1.9 Universities and Junior

Colleges. Tokyo: MEXT, 2012b. Available in: <http://www.mext.go.jp/ english/statistics/1302965.htm>. Accessed: 23 may 2015.

. Statistics. Tokyo: Ministry of Education, Culture, Sports, Science and Technology (MEXT), 2013. Available in: <http://www.mext.go.jp/ english/statistics/index.htm>. Accessed: 23 may 2015.

. Sūji de Miru Senshūgakkō. (The Specialized Training Colleges in numbers). Tokyo: MEXT, 2014. [in Japanese]. Available in: $<$ http://www.mext.go.jp/component/a_menu/education/detail/_icsFiles/ afieldfile/2014/12/25/1322361_5.pdf>. Accessed: 23 may 2015.

. The enactment of the school education law. Available in: $<$ http:// www.mext.go.jp/b_menu/hakusho/html/others/detail/1317423.htm>. Accessed: 11 ago 2015.

NEWBY, H.; WEKKO, T.; BRENEMAN, D.; JOHANNESON, T.; MAASEN, P. OECD Reviews of Tertiary Education. Japan; Paris: OECD, 2009.

NIAD-UE. Overview of the Quality Assurance System in Higher Education: Japan. Tokyo: National Institution for Academic Degrees and University Evaluation, 2014.

. Evaluation of Education and Research Activities at National

Universities. 2015a. Available in: $<$ http://www.niad.ac.jp/english/unive/ activities/1181758_1671.html>. Accessed: 11 ago 2015.

. NIAD-UE's Certified Evaluation and Accreditation. 2015b.

Available in: $<$ http://www.niad.ac.jp/english/unive/activities/1181757_1671. html $>$. Accessed: 11 ago 2015. 
OBA, Jun. Incorporation of National Universities in Japan: Reform Towards the Enhancement of Autonomy in Search of Excellence. Organization Reforms and University Governance: Autonomy and Accountability. Research Institute for Higher Education, Hiroshima University: COE Publication Series 11, dec., 2004.

OBA, Jun. Current State and Problems of Japanese Higher Education. Paper prepared for the seminar at "the Ministry of Higher Education and at the King Faisal Centre for Research and Islamic Studies" on 29 January 2005 in Riyadh, Saudi Arabia, 2005.

OBA, Jun. Creating World-Class Universities in Japan: Policy and Initiatives. Policy Futures in Education, Japan, v. 6, n. 5, p. 629-640, 2008.

POOLE, Gregory S. Higher Education Reform in Japan: Amano Ikuo on 'The University in Crisis'. International Education Journal, South Australia, v. 4, n. 3, p. 149-171, 2003.

SAITO, Yasuo. Higher Education in Japan. National Institute for Educational Policy Research, 2011. Available in: <http://www.nier.go.jp/ English/educationjapan/pdf/201109HE.pdf>. Accessed: 27 may 2015.

UNIVERSITY COUNCIL. "21 Seiki no Daigakuzō Kongo no Kaikaku Hōsaku ni tsuite". (A Vision for the Universities in the $21^{\text {st }}$ Century and Reform Measures). Tokyo: MEXT, 1998. (in Japanese). Available in: $<$ http://www.mext.go.jp/b_menu/shingi/old_chukyo/old_daigaku_index/ toushin/1315932.htm>. Accessed: 27 may 2015.

WATANABE, Eiji. Impact of University Evaluation on Education and Research. Japanese National University Reform in 2004. Tokyo: Center for National University Finance and Management, p.113-128, 2008.

YAMADA, Reiko. Gains in Learning Outcomes of College Students in Japan: Comparative Study between Academic Fields. The International Education Journal: Comparative Perspectives, Christchurch, v. 13, n. 1, p.100-118, 2014.

YONEZAWA, Akiyoshi. Function and Structure of Self-Evaluation in Japanese Higher Education. AAIR Conference 1999, 1-3 December, 1999. 
YONEZAWA, Akiyoshi. The Quality Assurance System and Market Forces in Japanese Higher Education. Higher Education, Springer, n. 43, p. 127139, 2002.

YONEZAWA, Akiyoshi. Japanese Flagship Universities at a Crossroads. Higher Education, Springer, n. 54, p. 483-499, 2007.

Ana Mami Yamaguchi - Hokkaido University of Education Saporo | Japan. Contato: anayamaguchi@gmail.com Shuichi Tsukahara - Kansai University of International Studies miki | japan. contato: tsukahara18900@gmail.com

Artigo recebido em 16 de outubro de 2015 e aprovado em 25 de novembo de 2015. 
